\title{
Geodiversity and Mining Towards the Development of Geotourism: A Global Perspective
}

Paúl Carrión-Mero ${ }^{1,2 *}$, Néstor Montalván-Burbano ${ }^{1,3}$, Geanella Herrera-Narváez ${ }^{1,2}$, Fernando Morante-Carballo ${ }^{1,4,5}$

${ }^{1}$ Centro de Investigación y Proyectos Aplicados a las Ciencias de la Tierra (CIPAT), ESPOL Polytechnic University, Campus Gustavo Galindo Km 30.5 via Perimetral, Guayaquil 09-01-5863, Ecuador

${ }^{2}$ Facultad de Ingeniería en Ciencias de la Tierra (FICT), ESPOL Polytechnic University, Campus Gustavo Galindo Km 30.5

via Perimetral, Guayaquil 09-01-5863, Ecuador

${ }^{3}$ Business and Economy Department, University of Almería, Carretera Sacramento s/n, La Cañada de San Urbano, Almería 04120, Spain

${ }^{4}$ Facultad de Ciencias Naturales y Matemáticas (FCNM), ESPOL Polytechnic University, Campus Gustavo Galindo Km. 30.5

Vía Perimetral, Guayaquil 9015863, Ecuador

${ }^{5}$ Geo-recursos y Aplicaciones GIGA, ESPOL Polytechnic University, Campus Gustavo Galindo Km. 30.5 Vía Perimetral, Guayaquil 9015863, Ecuador

Corresponding Author Email: pcarrion@espol.edu.ec

https://doi.org/10.18280/ijdne.160209

Received: 18 January 2021

Accepted: 2 April 2021

\section{Keywords:}

geodiversity, mining, geotourism, cultural heritage, bibliometric

\begin{abstract}
Geodiversity and geological heritage are considered to be parallel and closely related concepts of biodiversity and biological heritage. Biodiversity is based and exists on the geodiversity of a territory. In the same way, mining activity and mining heritage are distinguished as contributing to social and economic development. The mining heritage is linked to the geological heritage and has become increasingly important for its social value and relationship with tourist activities. This study aims to analyze these fields' intellectual structure through bibliometrics as a current and innovative methodology that allows a full understanding of their structure and the relationships between these fields of cultural heritage, geodiversity, mining and geotourism. The following methodology considered: i) Search for classified information with scientific rigour in an indexed database, using search descriptors that cover the objective set, ii) analysis of scientific articles through graphical and statistical output schemes, and iii) discussion of the contributions, methodologies used, and trends on the subject. 709 documents of 29 years (1990-2019) from the Scopus database were analyzed. The results show the main themes, countries and influential institutions in cultural heritage, geodiversity, mining and tourism, which address six major research topics ranging from sustainable mining to geodiversity. Extensive information and understanding are provided that other research has partially addressed, allowing current and potential research areas to be identified.
\end{abstract}

\section{INTRODUCTION}

The natural heritage conservation and its corresponding legislation have remained biased to the biotic context [1]. In contrast to a minimal group of international geological interest sites, and specific projects for the geosites conservation. Can be attributed to the lack of prominence in both geoscientists' professional looking and geosciences educative looking [2]. Despite the biotic bias, there are seven UNESCO Global Geoparks in Latin America: Araripe (Brazil), Palace Caves (Uruguay), Comarca Minera (México), High Mixteca (México), Imbabura (Ecuador), Andagua's Colca and Volcano (Peru) and Kutralkura (Chile) [3].

The Geoparks show that both natural and cultural heritage has an essential role in the relationships between human beings and their environment, considering the natural heritage as the set of assets, natural and environmental resources that the society has inherited from their predecessors [4]. Moreover, the cultural heritage as the set of tangible and intangible assets made of elements which reinforce the community sense, with the self-identity and the unique features of a human group, which are passed between generations [5]. The natural-cultural heritage emphasizes the natural elements that stay in their original context but are intervened by human beings. On the other hand, the geological heritage is an essential part of the natural heritage, and it is defined as a non-renewal natural resource, that is part of the common good and its part of the natural and cultural heritage of the humanity [6]. It is also used as an economic geo-resource, which requires identification and valuation for correct management, with a vision of sustainability [7].

The geoparks as Earth's parks have geodiversity, biodiversity and cultural heritage [8]. This concept directly associates the community with their territory, framed in the sustainable use of the resource, through geotourism, in a suitable legal and institutional framework [9]. The term of geodiversity is a useful concept for management and conservation of the abiotic heritage, whose incorporation is necessary for local policies of sustainable development and valuation of natural resources [10]. There is a natural variety of the geological and geomorphological characteristics, including their associations and contributions for the creation of landscapes [11, 12]. The geodiversity is related to geotourism, where the beautiful landscapes are appreciated, 
studied and enjoyed by the travellers [13]. Because of this, the geotourism according to the Carrión Mero et al. [14] is defined from the finality of appreciating the geological, geomorphological procedures and the natural resources of the landscape (relief, rocks, fossils), including passive recreational visits as admiration, appreciation and learning. Furthermore, the geotourism is considered according to Dunlop et al. [15] as a sustainable touristic segmentation, made by people who get interested in learning the geological and geomorphological aspects of a particular place, being this their primary travel motivation.

It is also understood as the touristic and sustainable promotion strategy of a place based on the dissemination of their geological heritage [2]. The geotourism has the potential of contribute to the sustainable development of the territory, benefiting zones with very different socio-economic realities [14], like the mining sector, where the sustainable mining takes an essential role in search of alternatives solutions in the sustainable development framework [16-18].

Given the importance of these academic fields and the relationships involved, it is necessary to analyze the geodiversity and mining fields' scientific production, using modern methods, like bibliometrics, which allows knowing its cognitive structure, evolution, and trends [19].

For this purpose, two main pathways were established. First, an analysis of the scientific production performance at evaluating documents, researchers, countries and journals of the thematic was done. In the second place, the intellectual structure and its evolution from using science maps using cooccurrence and co-citation networks were identified.

\section{MATERIALS AND METHODS}

\subsection{Bibliometric analysis}

The research field analysis requires a systematic process that allows mapping and evaluating its structure, using explicit and rigorous methods, which together are called systematic reviews of the literature [20]. These rigorous processes are applied similarly in bibliometric analyzes [21, 22].

Bibliometric analyzes first initiated by López-Muñoz et al. [23]. They allow to structure the knowledge of a specific field of study, through the quantitative analysis of its intellectual structure, patterns and evolution over time [24]. This type of analysis has carried out in various academic disciplines [25, 26], among them, the earth sciences [4].

In this study, a four-step methodology is used to collect information on the intellectual structure of the field of study to evaluate the performance of scientific production through the analysis of documents, countries and authors, and current topics and research trends.

\subsection{Defining search terms}

The selection of keywords for data collection includes the terms "geodiversity", "mining" and "geotourism", being terms of common use in geology. When referring to responsible mining as activity towards sustainable development, it is necessary to consider post-mining recovery, take advantage of mining exploitation areas, and promote sustainable tourism through thematic mining parks, underground museums, and touristic mines. It is essential to value geodiversity and rescue the geological and mining heritage [27-29].
Scopus database was selected, to evidence high-quality scientific material, being the largest database of citations and abstracts of peer-reviewed bibliography, based on two main characteristics: i) application of rigorous quality standards through Scimago Journal Rank (SJR) and Cite-score, ii) broad coverage in time compared to other databases, being Scopus the most suitable for analysis of citations with a considerable number of references stored as metadata [25, 30]. Reasons justify its use by allowing the validation of the indexed information.

The data collection was carried out in March 2020, based on the selected terms that allowed the identification of the study topics (descriptors), based on the titles, abstract and keywords, which allows establishing the search topic to identify the records of scientific production related to the subject of study [9]. These records provide a set of metadata that describes each of its attributes and is the primary source of information for this type of study. The search topic used descriptors and Boolean operators; it is summarized as follows: TS = (TITLE-ABS-KEY ("geopark") OR TITLE-ABS-KEY ("cultural heritage") OR TITLE-ABS-KEY ("geodiversity") OR TITLE-ABS-KEY ("mining") OR TITLE-ABS-KEY ("geotourism") AND TITLE-ABS-KEY ("sustainable development")). Based on these criteria, 6487 records were obtained.

\subsection{Refinement of search results}

With the information obtained, inclusion and exclusion criteria were applied in studies with a bibliometric approach [31]. The field of study was limited to the Earth and Planetary Sciences sub-area, obtaining 2,192 records. Only articles are considered in this process, excluding conference articles, books and chapters, editorials, notes and letters. This criterion is based on the fact that journal articles are considered certified knowledge [24]. Nine hundred seventy-six articles (976) were obtained.

Also, articles only in English were chosen because it is the language most used in various fields of knowledge and researchers worldwide [32], obtaining 774 documents. The period considered corresponds from the publication of the first document in the Scopus database (1990) to 2019. The year 2020 was excluded because not all documents corresponding to the year mentioned were available. Finally, 741 documents were obtained.

\subsection{Data cleaning and software selection}

The database was downloaded into an Excel spreadsheet for analysis, including relevant information related to scientific production: title, author details (names and affiliation), keyword, abstract, citation count, journals and references.

In the downloaded database, processing was carried out to clean the data and ensure its quality. Records without author, duplicates and not related to the research topic were eliminated, which finally made it possible to obtain 709 documents.

Data processing and performance analyzes were performed manually using the Microsoft Office Excel tool. Additionally, the VOSviewer software was used, which allows the construction and visualization of bibliometric maps based on two-dimensional spacing [33]. Moreover, it allows revealing the study field's cognitive structure, using various easily interpretable bibliometric maps such as the occurrences of author keywords, co-citation of authors and co-citation of 
journals [34, 35]. VOSviewer has been used as a tool for analyzing various fields of knowledge [36, 37], as well as those related to the natural sciences [38].

\section{RESULTS AND DISCUSSION}

This study presents an analysis of the scientific publications published in geology related to "Geodiversity and Mining" oriented to the development of geotourism during the period 1990-2019. This section shows results related to the performance analysis of the scientific production and bibliometric maps.

\subsection{Performance analysis}

\subsubsection{Scientific production analysis}

The evolution of scientific production is shown in Figure 1, where the last 19 years is concentrated at $92.30 \%$ and duplicated in 10 years after starting the subject of study. The analysis indicated that the field of study has resulted in a total of 709 records, which for analysis purposes have been divided into three time periods which we examine below:

Period I (1990-2000), the growth pattern is slow at first and extends until the year 2000; it has 55 scientific articles $(7.70 \%$ of the total) and 35 citations (7.04\%). The first published article that mentions the subject is "Minerals, materials and developing countries-a forward look" [39], this deals with the mineral development that promises to be a significant vehicle for economic growth and mentions an overall framework on issues of mineral and material needs of the developing world is shown in the context of "sustainable development". On the other hand, the year 2000 shows the highest scientific production of the period with 12 articles and nine citations. The article "Sustainable development of natural resources: Implications for mining of minerals" shows the concepts and practices in sustainable development to attempt a framework of strategies for the mineral industry [40].

In this period, some authors contributed with studies related to mining and environmental responsibility, where the company must make economic, ecological, and social considerations [41], action programs for sustainable exploitation of mineral resources [39] or hydric resources [42], as well as the consideration of reducing the use of industrial coal and $\mathrm{SO}_{2}$ emissions [43]. The mining company must show a commitment to sustainable development to achieve trust from society [44], which allows the participation of stakeholders who are directly or indirectly affected by its activities [45]. The government and international organizations are involved in sustainable mining development, where the government implements laws [46] and the proposed by international organizations [47].

Period II (2001-2010), observed that in 2002, there was a substantial increase in scientific production until 2010 with a production of 248 articles $(34.89 \%)$ and 151 citations. The year 2006 stands out in this period, registering 43 articles $(6.05 \%)$. The most relevant and cited article was "A geomorphological approach to the management of rivers contaminated by metal mining" which deals with current and historical metal mining, river channels and floodplains in many parts of the world that have been contaminated with metal-rich wastes in concentrations that can pose a danger to human livelihoods and sustainable development [48].

Some studies in this period continue in the line of mining and environmental responsibility when considering: i) The water resource. When researching the overexploitation of aquifers [49], contamination of rivers [48], the impact of agriculture and coal mining as pollutants of groundwater [50], and the effects of climate change on this supply [51] and, ii) The land resource, where mining plays an important role, by establishing environmental assessment systems [52], rules for sustainable development [53], obtaining data accurate to quantify mineral trends and environmental aspects [54] and their contaminants [55].

Period III (2011-2019), In this last phase, 406 articles are shown $(57.40 \%)$ and has 311 citations. The year 2017 shows the highest production of 66 documents; The article "The world's lead-zinc mineral resources: Scarcity, data, issues and opportunities" stands out, which deals with analysis and review of additional aspects that affect the future sustainability of $\mathrm{Pb}-\mathrm{Zn}$ resources, governed by economic factors, prevailing social and environmental issues, much more than mere resource constraints [56].

In this period, some researchers recognize the importance of global soils in urban ecosystems [57] and the changes in land cover that need to be monitored using modern techniques [58]. Geodiversity and its integration into society are considered by providing economic, social, cultural, and environmental benefits [59] and the importance of geological heritage [60]. Other researchers consider the pollution caused by abandoned mining sites [61], agricultural soils by heavy metals [62, 63], and natural and anthropogenic sources [64].

In recent years, the importance of mining and sustainable development has been recognized for the protection of the environment and the reduction of pollution in mineral extraction and processing sites [65], technological development for clean mining [66], energy savings, and energy efficiency in the sector [67], as well as mixed reality simulations for compression and operation of mines [68].

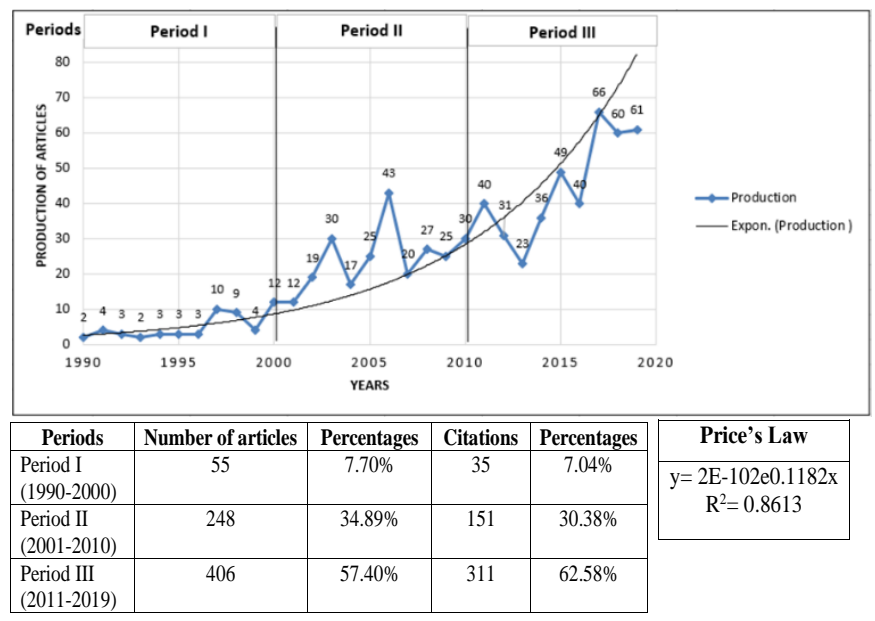

Figure 1. Scientific production growth of Geodiversity

\subsubsection{Frequently cited documents}

When analyzing a field of study, it is essential to know those relevant documents according to the citations obtained [22]. Table 1 is presented 15 documents with the most extensive citations in the area and the total period of study (1990-2019). The most cited article is "Aquifer overexploitation: What does it mean?", which exposes the implementation of groundwater management measures, quantitatively studying the aquifer with multidisciplinary human teams in reliability infrastructure [49]. The second article, named "A 
geomorphological approach to the management of rivers contaminated by metal mining" with 167 citations that deal with contamination by metal-rich wastes that represent a danger to human beings [48].

Table 1 shows the publications that make up the top 15 most cited documents in the area.

Table 1. Authors and frequently cited documents

\begin{tabular}{|c|c|c|c|}
\hline Ranks & Author/Year & Title & Citations \\
\hline 1 & Custodio, $2002[49]$ & Aquifer overexploitation: What does it mean? & 278 \\
\hline 2 & $\begin{array}{l}\text { Macklin et al., } 2006 \\
{[48]}\end{array}$ & A geomorphological approach to the management of rivers contaminated by metal mining & 167 \\
\hline 3 & $\begin{array}{l}\text { Streets et al., } 2000 \\
\text { [43] }\end{array}$ & Sulfur dioxide emissions in Asia in the period 1985-1997 & 133 \\
\hline 4 & Sun et al., 2008 [51] & $\begin{array}{l}\text { Impacts of multiple stresses on water demand and supply across the southeastern United } \\
\text { States }\end{array}$ & 126 \\
\hline 5 & Hose, 2012 [69] & 3G's for Modern Geotourism & 116 \\
\hline 6 & $\begin{array}{l}\text { Bridge, G., } \\
\text { McManus, } 2000 \text { [70] }\end{array}$ & $\begin{array}{c}\text { Sticks and stones: Environmental narratives and discursive regulation in the forestry and } \\
\text { mining sectors }\end{array}$ & 113 \\
\hline 7 & $\begin{array}{c}\text { Guo \& Wang, } 2004 \\
{[50]}\end{array}$ & $\begin{array}{c}\text { Hydrogeochemical processes in shallow quaternary aquifers from the northern part of the } \\
\text { Datong Basin, China }\end{array}$ & 103 \\
\hline 8 & $\begin{array}{l}\text { Joyce, S., Thomson, } \\
2000[71]\end{array}$ & Earning a social licence to operate: Social acceptability and resource & 87 \\
\hline 9 & $\begin{array}{l}\text { Morel et al., } 2014 \\
\text { [57] }\end{array}$ & $\begin{array}{c}\text { Ecosystem services provided by soils of urban, industrial, traffic, mining, and military areas } \\
\text { (SUITMAs) }\end{array}$ & 85 \\
\hline 10 & $\begin{array}{l}\text { Khalil et al., } 2013 \\
\text { [61] }\end{array}$ & $\begin{array}{c}\text { Assessment of soil contamination around an abandoned mine in a semi-arid environment } \\
\text { using geochemistry and geostatistics: Pre-work of geochemical process modeling with } \\
\text { numerical models }\end{array}$ & 82 \\
\hline 11 & $\begin{array}{l}\text { Esmaeili et al., } 2014 \\
\text { [62] }\end{array}$ & $\begin{array}{c}\text { A geochemical survey of heavy metals in agricultural and background soils of the Isfahan } \\
\text { industrial zone, Iran }\end{array}$ & 77 \\
\hline 12 & $\begin{array}{l}\text { Glaister \& Mudd, } \\
\quad 2010[72]\end{array}$ & $\begin{array}{l}\text { The environmental costs of platinum-PGM mining and sustainability: Is the glass half-full or } \\
\text { half-empty? }\end{array}$ & 75 \\
\hline 13 & Mudd, 2007 [54] & An analysis of historic production trends in Australian base metal mining & 73 \\
\hline 14 & Zouros, 2004 [73] & The European Geoparks Network & 70 \\
\hline 15 & $\begin{array}{l}\text { Gordon et al., } 2012 \\
\text { [59] }\end{array}$ & Engaging with geodiversity-why it matters & 70 \\
\hline
\end{tabular}

3.1.3 Contributions by country and region

Table 2. Contributions by countries and regions

\begin{tabular}{|c|c|c|}
\hline Geographical region & No. of papers & No. of citations \\
\hline \multicolumn{3}{|c|}{ Asia } \\
\hline China & 90 & 810 \\
\hline India & 40 & 178 \\
\hline \multicolumn{3}{|c|}{ America } \\
\hline \multicolumn{3}{|c|}{ North America } \\
\hline United States & 71 & 1151 \\
\hline Canada & 54 & 432 \\
\hline \multicolumn{3}{|c|}{ South America } \\
\hline Brazil & 19 & 110 \\
\hline \multicolumn{3}{|c|}{ Europe } \\
\hline Spain & 26 & 519 \\
\hline Italy & 25 & 302 \\
\hline France & 17 & 340 \\
\hline Russian Federation & 16 & 42 \\
\hline \multicolumn{3}{|c|}{$\begin{array}{r}\text { Northwestern Europe } \\
\end{array}$} \\
\hline United Kingdom & 61 & 706 \\
\hline \multicolumn{3}{|c|}{ Central Europe } \\
\hline Germany & 29 & 214 \\
\hline Poland & 24 & 141 \\
\hline \multicolumn{3}{|c|}{ Southwest Europe } \\
\hline Portugal & 15 & 248 \\
\hline \multicolumn{3}{|c|}{ Oceania } \\
\hline Australia & 58 & 821 \\
\hline \multicolumn{3}{|c|}{ Africa } \\
\hline \multicolumn{3}{|c|}{ Southern Africa } \\
\hline South Africa & 44 & 208 \\
\hline
\end{tabular}

Several researchers worldwide can link their knowledge, skills and experience through their contribution to scientific production [24]. Table 2 shows the 15 most significant contributions by country, ordered by region, which shows Asia, America, Europe, Oceania and Africa-considering that the field of study is globalized.

Also, it is necessary to analyze the contributions according to their citations. Figure 2 shows the top 15 countries in scientific production in this field of study and their citations.

China is the greatest exponent in the subject ( 90 documents and 810 citations). The United States in second place (71 documents and 1,151 citations) and the United Kingdom in third place (61 documents and 706 citations). The greater the production, the greater the number of citations, as in China and the United States.

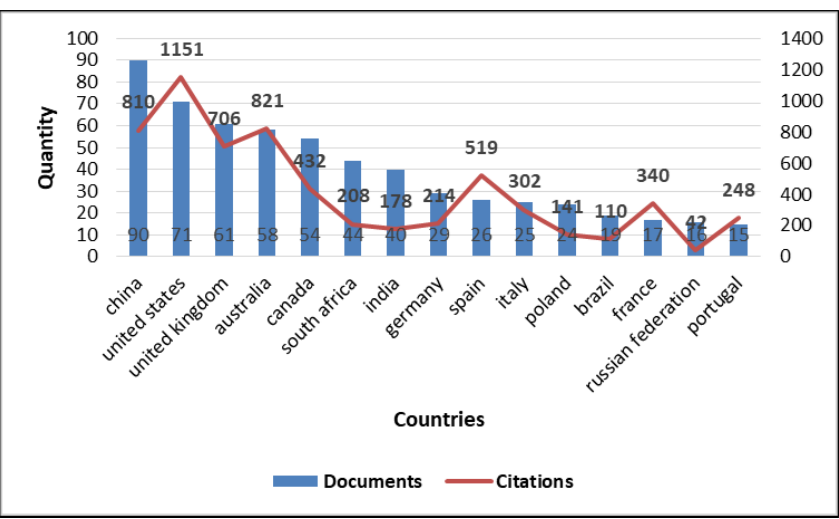

Figure 2. Scientific production of documents and citations by country

3.1.4 Influential authors

The fifteen principal authors with contributions in this field 
of study are shown in Table 3 , together with other indicators that allow us to obtain more information from the researchers, such as their institutional affiliation, country, publications and the H-Index [74]. We found Scoble M, (7 articles; H-Index 22), while the author (H-Index 92) is Chen L. It can be observed that there is no direct relationship between the amount of production of this field of study and the H-Index for each author.

Table 3. Scientific production of documents and citations by author

\begin{tabular}{|c|c|c|c|c|c|}
\hline Ranks & Author & Affiliation & Country & Productions & H-Index \\
\hline 1 & Scoble M. & The University of British Columbia & Canada & 7 & 22 \\
\hline 2 & Li X. & China Institute of Atomic Energy & China & 6 & 59 \\
\hline 3 & Li J. & Nanjing Agricultural University & China & 5 & 15 \\
\hline 4 & Veiga M. & Universidade da Coruña & Spain & 5 & 40 \\
\hline 5 & Wang Y. & Beijing Institute of Technology & China & 5 & 35 \\
\hline 6 & Liu X. & Jiangnan University & China & 4 & 22 \\
\hline 7 & Mudd G. & RMIT University & Australia & 4 & 35 \\
\hline 8 & Richards J. & Beckman Institute & United States & 4 & 41 \\
\hline 9 & Wu F. & Beijing Institute of Technology & China & 4 & 82 \\
\hline 10 & Zhao Y. & Shandong University & China & 4 & 25 \\
\hline 11 & Benzaazoua M. & Universite du Quebec en Abitibi-Temiscamingue & Canada & 3 & 35 \\
\hline 12 & Bounouala M. & Université Badji Mokhtar - Annaba & Algeria & 3 & 4 \\
\hline 13 & Chen L. & Pennsylvania State University & United States & 3 & 92 \\
\hline 14 & Corder G.D. & The University of Queensland & Australia & 3 & 19 \\
\hline 15 & Hakkou R. & Université Cadi Ayyad & Morocco & 3 & 18 \\
\hline
\end{tabular}

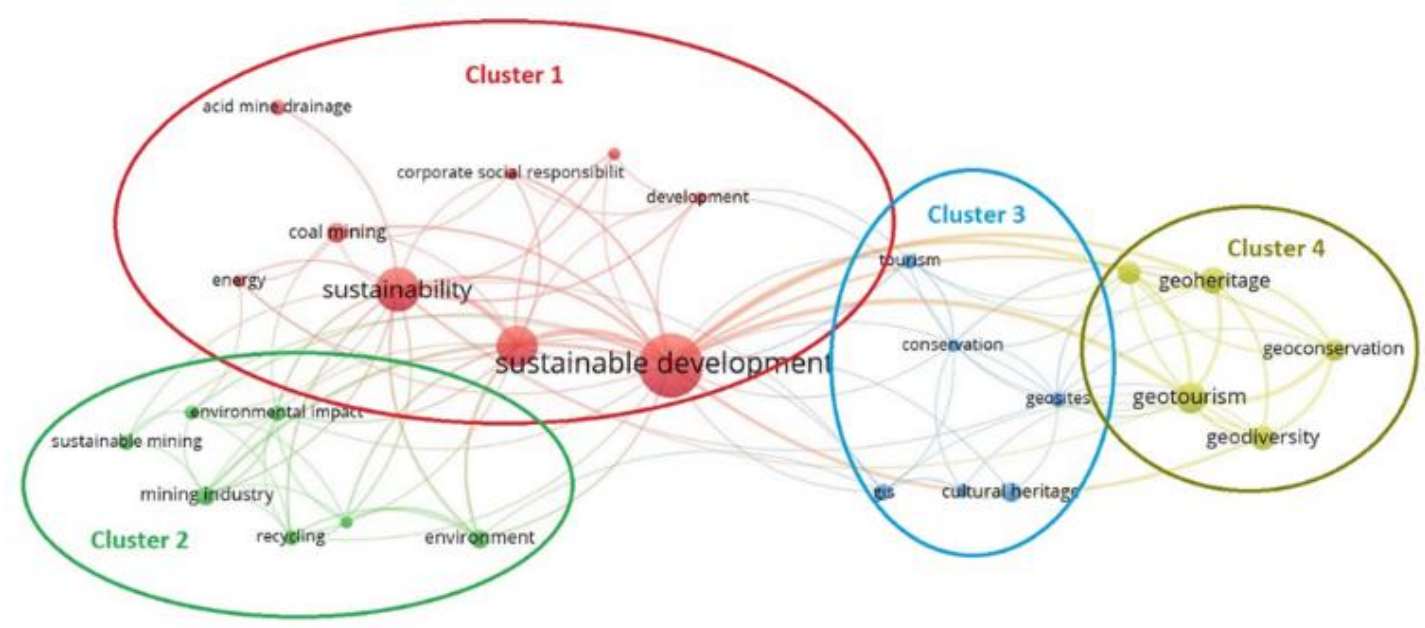

Figure 3. Author keyword co-occurrence network

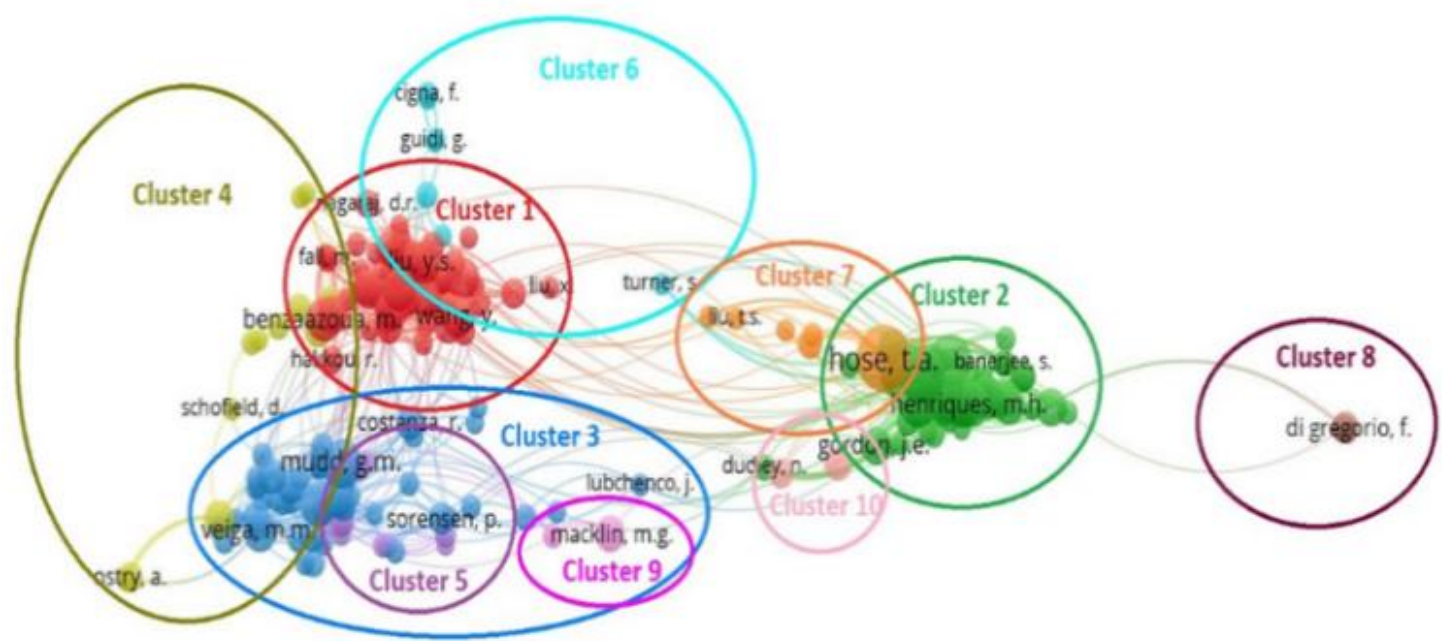

Figure 4. Reference author co-citation network 


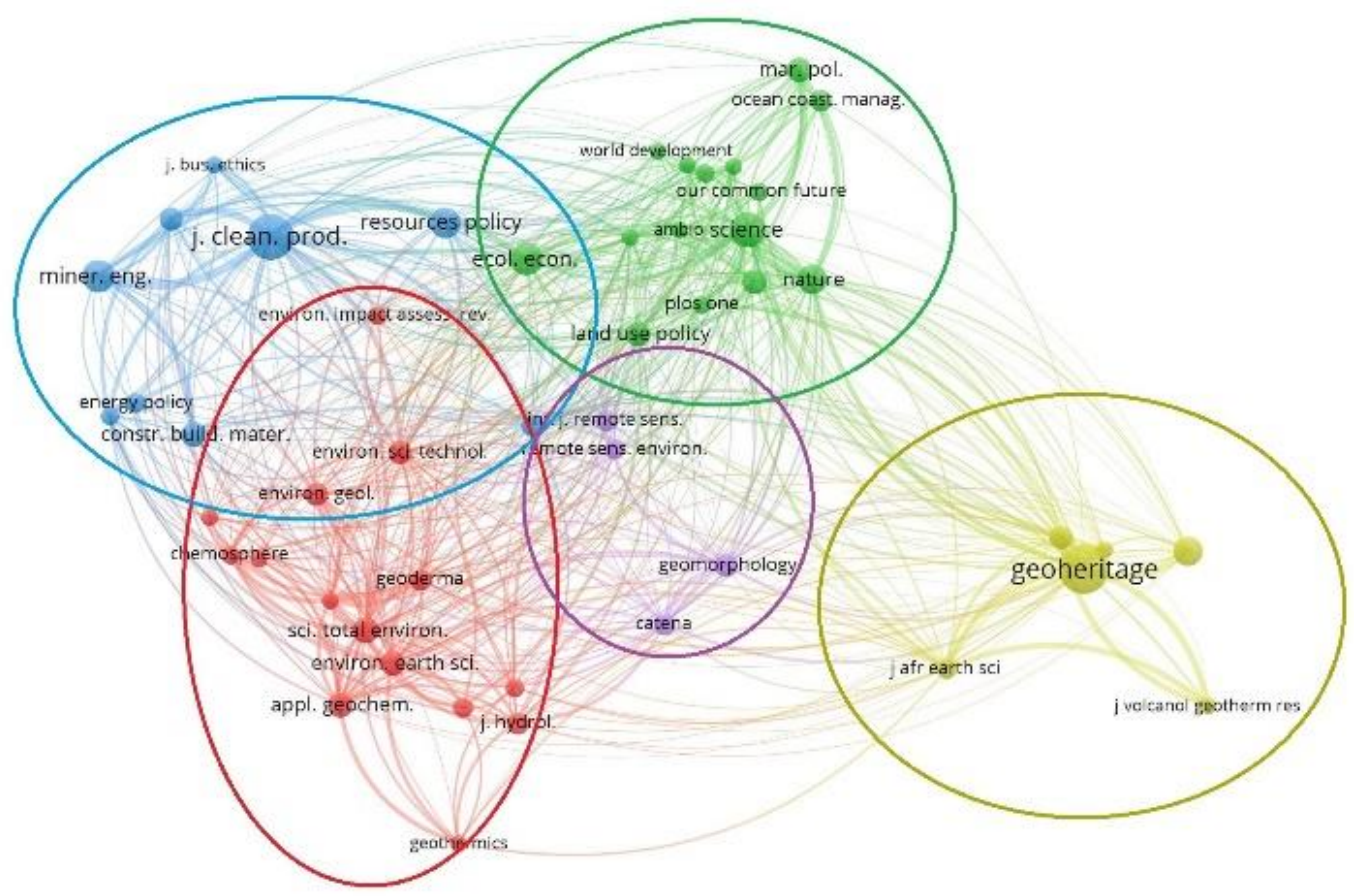

Figure 5. Scientific journal co-citation network

\subsection{Analysis of the intellectual structure}

When studying the intellectual structure of a given field of science, some researchers have opted for modern visualization methods known as bibliometric maps, when a significant volume of documents needs to be analyzed [75]. These have allowed academics and researchers to study a wide range of science disciplines. In this section, the VOS viewer software is used to generate maps of co-occurrences and co-citations, which allow us to observe the similarities of the field of research studied [76]. In these maps, nodes and links are easily observed. The first term (nodes) allows to identify the unit of analysis (keywords, authors, countries), and its size is determined by the frequency of appearance and the relationship between the nodes is configured by the links, whose width reveals their strength $[22,77]$.

\subsubsection{Author keywords co-occurrence network}

It is a content analysis that uses keywords to understand the research area's conceptual structure, allowing to observe concepts and topics, for which it uses nodes and clusters respectively [33]. From 1787 keywords provided by the authors of this field of study, a co-occurrence network is built, which considers 27 keywords, which have been cited at least five times. Figure 3 is obtained from this, where the structure and trends of this field of study are observed. Four clusters of colours are identified that relate the areas of knowledge (main research topics) and show the author's words represented in nodes (topics).

Cluster 1 (red) has been called "Mining and Sustainable", relating the awareness of the local population about mining and sustainability, which promotes ecologically important sites [78-80]. The most important terms in this cluster are Sustainable development, Sustainability and Mining, with 271 occurrences.

Cluster 2 (green) defined "Clean mining energies", which deals with the strategies developed in mining areas to promote the ecologically sustainable development of the environment [81-83]. The terms that stand out in this cluster are
Environment, Mining industry and Recycling with 55 occurrences.

Cluster 3 (blue) represents the area of "Cultural heritage and sustainable tourism", illustrating the challenges and opportunities of geoinformatics to improve the protection of Cultural Heritage $(\mathrm{CH})$ and promote sustainable tourism [8486]. The most important terms in this cluster are Cultural heritage, GIS and Geosites with 47 occurrences.

Finally, cluster 4 (yellow) belonging to the area "Geodiversity" with the keywords "Geotourism", "Geoheritage" and "geodiversity", that relates the various landscapes and geological, geomorphological and archaeological sites that could be used to explain the history of the earthy the regional climate changes. Moreover, that can serve as a model for the sustainable development of Geotourism, preserve geological and archaeological heritage, and contribute to establishing a geopark $[69,87,88]$. The most representative terms are Geotourism, Geoheritage and Geodiversity with a total of 100 occurrences.

\subsubsection{Reference author co-citation network}

The purpose of this network's construction is to recognize the outstanding authors who have been linked as references for the confirmation of the intellectual structure of these fields of study [34, 35]. This network contains: the authors of references' information, considering those cited at least ten times or more, where 205 authors fulfil this criterion in Figure 4 , involving topics related to knowledge such as geochemistry within mining, geodiversity and environment within a context of sustainable development.

Cluster 1 (red) has been called "Geochemistry mining", who is most outstanding authors are Benzaazoua, M.; Wang, Y.; Wang, J. and Chen, J. with a total of 1054 citations in research topics about the geochemical behaviour of mining waste.

Cluster 2 (green) is defined in the area of "Geodiversity" with prominent authors such as Dowling, R.K.; Brilha, J.; Gray, M. and Zouros, N. with a total of 1100 citations, which address issues of geopark, geographic heritage and 
geoconservation in a place marked by a relevant geological heritage.

Cluster 3 (blue) called "Environmental" with representative authors such as Mudd, G.M.; Hilson, G.; Veiga, M.M. and Graedel, T.E. with a total of 742 citations that relate sustainability and mining issues as a critical trend in extraction, production and its environmental implications for the future.

Cluster 4 (yellow) known as "Mining and Sustainable development", whose outstanding authors are Scoble, M.; Younger, P.L.; Ostry, A.; Edmunds, W.M. with a total of 174 citations in topics about sustainable development in the minerals industry.

Cluster 5 (purple) called "Georesources", where the outstanding authors of this group are Scholz, R.W.; Wellmer, F.-W.; Randers, J. and Langer, W.H. with a total of 128 citations; their research topics are related to chemical element reserves and resources for sustainable action.

Cluster 6 (turquoise) called "Geoscience", with authors such as Xiao, W.; Cigna, F.; Tapete, D. and Turner, S. who have a total of 80 citations on topics related to the area of geoscience and remote sensing of the study about Earth.

Cluster 7 (orange) known as "Geotourism", whose outstanding authors are Hose, T.A.; Jary, Z.; Vasiljević, D.A.; Liu, T.S. with a total of 148 citations that deal with topics about geotourism through geological interpretation and promotion of geoconservation.

Cluster 8 (brown) named "Geoheritage", with prominent authors such as Di Gregorio, F.; De Waele, J. and Barca, S. with a total of 49 citations on topics related to the conservation and appreciation of geological heritage.

Cluster 9 (lilac) known as "Chemical and physical impact in mining", whose lead authors are Macklin, M.G. and Hudson-Edwards, K.A. with a total of 40 citations, dealing with chemical and physical impacts of mine tailings on river systems for sustainable watershed management.

Finally, cluster 10 (pink) called "Geomorphology", whose outstanding authors are Galal, A and Paulo, A with 41 citations and deal with topics about the preservation and geodiversity of geomorphology for the economic development of a region.

\subsubsection{Scientific journal co-citation network}

The analysis allows us to observe the study field's structure according to the reference journals that have allowed its construction [75, 89]. In this network's configuration, the threshold of at least 20 co-citations established, which has allowed us to consider 49 journals that meet the requirement. The co-citation journals network showed in Figure 5, where the thematic groupings are differentiated by colour.

Cluster 1 (red) called "Environmental Science" comprises 15 nodes and a total of 472 citations, highlighting Science of the Total Environment, Applied Geochemistry and Environmental Earth Sciences, are considered journals for publications on the environment, which includes the environment of the Earth's crust and atmosphere.

Cluster 2 (green), called "Science Multi-disciplinary", comprises 15 nodes and a total of 574 citations, highlighting the journals Science, Ecological Economics and Nature, magazines that present scientific news, commentaries and cutting-edge research.

Cluster 3 (blue) named "Renewable Energy, Sustainability and the Environment", comprises nine nodes and a total of 482 citations, highlighting Journal of Cleaner Production, Minerals Engineering and Resources Policy, which focus on research, cleaner production practice, environment and sustainability.
Cluster 4 (yellow), called "Earth and Planetary Sciences" contains six nodes and a total of 340 citations, highlighting Geoheritage, Episodes and Proceedings of the Geologists Association, which address issues on aspects of global geological heritage, contributing to the conservation of sites and materials, their interpretation through education, training and tourism.

Finally, cluster 5 (purple) known as "Earth-surface Processes" comprises four nodes and a total of 137 citations, highlighting the journals Geomorphology, International Journal of Remote Sensing and Catena, which stand out in geomorphological issues of tectonics, regional structure, glacial processes, geographical features, river sequences and climate change.

\section{CONCLUSIONS}

This study offers an analysis of the intellectual structure of the fields of cultural heritage, geodiversity, mining and tourism through bibliometrics methods. Academic publications were examined which are located in the Scopus database for the period 1990- 2019. A total of 709 documents were examined due to a rigorous methodological process of compilation and selection, obtaining a transparent and replicable process, making possible the full analysis of the studied area.

The results obtained in connection with the performance analysis, show three decades of thematic development, where the last period (2010-2019) concentrates the highest production $(57.40 \%)$ demonstrating the increasing interest of the study field. This interest is perceived by the contributions of 84 countries located in five continents which the most important by production are, Asia (China, India), America (United States, Canada, Brazil), Europe (United Kingdom, Spain, Italy, France, Russian Federations), Oceania (Australia) and Africa (South Africa), where China, and United States reports the highest contributions. In the case of the researchers that have cooperated with the field development are Scoble M. (The University of British Columbia), Li X. (China Institute of Atomic Energy) and Li J. (Nanjing Agricultural University).

According to the concerned analyses of the intellectual structure, there are some results to consider:

Firstly, the co-occurrence analysis of the author keywords, show four relevant themes of this study field and 27 topics, whose themes denominated "Mining and Sustainable", "Clean mining energies", "Cultural heritage and Sustainable tourism" and "Geodiversity". The largest cluster corresponds to "Mining and Sustainable" with 271 topics, where Sustainability development, Sustainability and Mining are highlighted. These studies show how the community is sensitive to the effects of mining and sustainability.

Secondly, the co-citation analysis of the reference authors includes ten groups that represent the diverse themes related with "Geochemistry Mining", "Geodiversity", "Environmental", "Mining and Sustainable development", "Georesources", "Geoscience", "Geotourism", "Geoheritage", "Chemical and physical impact in mining" and "Geomorphology". The clusters are led by researchers in their areas, "Geodiversity" Brilha, J., Gray M., and Zouros N.; "Mining and Sustainable development" M. Scoble, P.L Younger, A. Ostry and W.M. Edmunds.

Thirdly, the bibliometric map of co-citation by journal shows the most influential journals for the construction of the 
intellectual structure, in five clusters that are related in significant thematic areas: "Environmental Science", "Science Multi-disciplinary", "Renewable Energy, Sustainability and the Environment", "Earth and Planetary Sciences" and "Earthsurface Processes" - distinguishing the journals: Geoheritage, Journal of Cleaner Production and Sustainability and the Environment.

Fourth, this type of analysis makes it possible to visualize the entire field of study, where the main topics it addresses can be observed, and the relationships between various topics that have been proposed by authors or researchers in the study period. This represents an innovation in academia since systematic reviews of the literature allow a partial focus on a topic in the field of study.

This bibliometric study reflects guidelines to address topics, and subtopics are created while integrating to analyze current issues. In this case, in mining, geodiversity, geomorphology and geotourism, in recent years, guidelines related to geoheritage have been strengthened, or the need to establish sustainable development guidelines in industrial mining activities.

Many aspects that are related with the analysis of the intellectual structure are considered and show that: i) Is evidenced an increment in the researches related to the fields of cultural heritage, geodiversity, mining and tourism; ii) The investigation area of "Mining and Sustainable development" has a recent development in handling two sensitive themes with a potential development; iii) In the geosciences area there is sustainable development in the areas of "Georesources", "Geoscience", "Geotourism", "Geoheritage" which have managed to combine between them.

Additionally, it is necessary to know the limitations that the present study: i) The use of the Scopus database and not to consider the use of other bases like Web of Science and Dimensions; ii) Consider the publications in the English language instead of review all the spectrum of the contributions in other languages; iii) Exclude diverse types of documents by only considering articles. Finally, bibliometric research allows vast knowledge through modern techniques in a review of scientific literature.

\section{REFERENCES}

[1] Pourfaraj, A., Ghaderi, E., Jomehpour, M., Ferdowsi, S. (2020). Conservation management of geotourism attractions in tourism destinations. Geoheritage, 12(4): 121. https://doi.org/10.1007/s12371-020-00500-4

[2] Reynard, E., Giusti, C. (2018). The landscape and the cultural value of geoheritage. In Geoheritage, 147-166. https://doi.org/10.1016/B978-0-12-809531-7.00008-3

[3] Luis Sanchez-Cortez, J., Simbana-Tasiguano, M. (2018). Geoparks and their implantation in Latin America. Estudios Geograficos, 79(285): 445-467. https://doi.org/10.3989/estgeogr.201817

[4] del Río-Rama, M.D.L.C., Maldonado-Erazo, C.P., Álvarez-García, J., Durán-Sánchez, A. (2020). Cultural and natural resources in tourism Island: Bibliometric $\begin{array}{lll}\text { mapping. } & \text { Sustainability, } & 12(2) \text { : }\end{array}$ https://doi.org/10.3390/su12020724

[5] Silva, H.E., Henriques, F.M. (2021). The impact of tourism on the conservation and IAQ of cultural heritage: The case of the Monastery of Jerónimos (Portugal). Building and Environment, 190: 107536. https://doi.org/10.1016/j.buildenv.2020.107536

[6] Sallam, E.S., Abd El-Samee, M.A., Bobrysheva, O.R., Yashalova, N.N., Ruban, D.A. (2020). Geological heritage of Luxor and its vicinities, Egypt: A new assessment and geotourism perspectives. Arabian Journal of Geosciences, 13(2): 1-14. https://doi.org/10.1007/s12517-019-5038-0

[7] Fesharaki, O., Calonge, A., Carrillo, M.D.L. (2020). The educational role of geology olympiads in Spain: Promotion of geological heritage and geoconservation in Youngsters. Geoheritage, 12(4): 1-12. https://doi.org/10.1007/s12371-020-00521-z

[8] Herrera-Franco, G., Montalván-Burbano, N., CarriónMero, P., Jaya-Montalvo, M., Gurumendi-Noriega, M. (2021). Worldwide research on geoparks through bibliometric analysis. Sustainability, 13(3): 1175. https://doi.org/10.3390/su13031175

[9] Quesada-Román, A., Pérez-Umaña, D. (2020). Tropical paleoglacial geoheritage inventory for geotourism management of Chirripó National Park, Costa Rica. Geoheritage, 12(3): $1-13$. https://doi.org/10.1007/s12371-020-00485-0

[10] Sendjaja, P., Suparka, E., Botjing, M.U. (2020). Geodiversity of the Togean Islands National Park, Central Sulawesi Province for geopark assessment. In IOP Conference Series: Earth and Environmental Science, 589(1): 012023. https://doi.org/10.1088/1755$1315 / 589 / 1 / 012023$

[11] Ibáñez, J.J., Brevik, E.C., Cerdà, A. (2019). Geodiversity and geoheritage: Detecting scientific and geographic biases and gaps through a bibliometric study. Science of the Total Environment, 659: 1032-1044. https://doi.org/10.1016/j.scitotenv.2018.12.443

[12] Quesada-Román, A., Pérez-Umaña, D. (2020). State of the art of geodiversity, geoconservation, and geotourism in Costa Rica. Geosciences, 10(6): 211. https://doi.org/10.3390/geosciences10060211

[13] Hose, T.A. (2016). Three centuries (1670-1970) of appreciating physical landscapes. Geological Society, London, Special Publications, 417(1): 1-23. https://doi.org/10.1144/sp417.0

[14] Carrión Mero, P., Herrera Franco, G., Briones, J., Caldevilla, P., Domínguez-Cuesta, M.J., Berrezueta, E. (2018). Geotourism and local development based on geological and mining sites utilization, ZarumaPortovelo, Ecuador. Geosciences, 8(6): 205. https://doi.org/10.3390/geosciences8060205

[15] Dunlop, L., Larwood, J.G., Burek, C.V. (2018). Geodiversity action plans-a method to facilitate, structure, inform and record action for geodiversity. In Geoheritage, 53-65. https://doi.org/10.1016/B978-0-12809531-7.00003-4

[16] Ferraro, F.X., Schilling, M.E., Baeza, S., Oms, O., Sá, A.A. (2020). Bottom-up strategy for the use of geological heritage by local communities: Approach in the "Litoral del Biobío" Mining Geopark project (Chile). Proceedings of the Geologists' Association. https://doi.org/10.1016/j.pgeola.2020.06.001

[17] Beretić, N., Đukanović, Z., Cecchini, A. (2019). Geotourism as a development tool of the Geo-mining Park in Sardinia. Geoheritage, 11(4): 1689-1704. https://doi.org/10.1007/s12371-019-00379-w

[18] García-Sánchez, L.A., Alvarado-Sizzo, I., Palacio-Prieto, J.L. (2020). Geoturismo y acción participativa: 
Estrategia de conservación del patrimonio geológico en el distrito minero de Tlalpujahua-El Oro, México. AGER. Revista de Estudios sobre Despoblación y Desarrollo Rural, 29: 203-235. https://doi.org/10.4422/ager.2020.10

[19] Cobo, M.J., López-Herrera, A.G., Herrera-Viedma, E., Herrera, F. (2011). An approach for detecting, quantifying, and visualizing the evolution of a research field: A practical application to the fuzzy sets theory field. Journal of informetrics, 5(1): 146-166. https://doi.org/10.1016/j.joi.2010.10.002

[20] Tranfield, D., Denyer, D., Smart, P. (2003). Towards a methodology for developing evidence-informed management knowledge by means of systematic review. British Journal of Management, 14(3): 207-222. https://doi.org/10.1111/1467-8551.00375

[21] Fahimnia, B., Sarkis, J., Davarzani, H. (2015). Green supply chain management: A review and bibliometric analysis. International Journal of Production Economics, 162: 101-114. https://doi.org/10.1016/j.ijpe.2015.01.003

[22] Carrión-Mero, P., Montalván-Burbano, N., Paz-Salas, N., Morante-Carballo, F. (2020). Volcanic geomorphology: A review of worldwide research. Geosciences, 10(9): 347. https://doi.org/10.3390/geosciences10090347

[23] López-Muñoz, F., Alamo, C., Quintero-Gutiérrez, F.J., García-García, P. (2008). A bibliometric study of international scientific productivity in attention-deficit hyperactivity disorder covering the period 1980-2005. European Child \& Adolescent Psychiatry, 17(6): 381391. https://doi.org/10.1007/s00787-008-0680-1

[24] Briones-Bitar, J., Carrión-Mero, P., Montalván-Burbano, N., Morante-Carballo, F. (2020). Rockfall research: A bibliometric analysis and future trends. Geosciences, 10(10):

403. https://doi.org/10.3390/geosciences10100403

[25] Durán-Sánchez, A., Del Río, M.D.L.C., Rama, J.Á.G., Fernando, D. (2019). Journal of Enterprising Communities: People and Places in the Global Economy. https://doi.org/10.1108/JEC-10-2018-0072

[26] Maldonado-Erazo, C.P., Álvarez-García, J., del RíoRama, M.D.L.C., Correa-Quezada, R. (2020). Corporate social responsibility and performance in SMEs: Scientific coverage. Sustainability, 12(6): 2332. https://doi.org/10.3390/su12062332

[27] Aznar-Sánchez, J.A., Velasco-Muñoz, J.F., BelmonteUreña, L.J., Manzano-Agugliaro, F. (2019). Innovation and technology for sustainable mining activity: A worldwide research assessment. Journal of Cleaner Production, 221: $38-54$ https://doi.org/10.1016/j.jclepro.2019.02.243

[28] Carrión-Mero, P., Loor-Oporto, O., Andrade-Ríos, H., Herrera-Franco, G., Morante-Carballo, F., JayaMontalvo, M., Berrezueta, E. (2020). Quantitative and qualitative assessment of the "el sexmo" tourist gold mine (zaruma, ecuador) as a geosite and mining site. Resources, 9(3):

28. https://doi.org/10.3390/resources9030028

[29] Herrera Franco, G., Carrion Mero, P., Morante Carballo, F., Herrera Narváez, G., Briones Bitar, J., Blanco Torrens, R. (2020). Strategies for the development of the value of the mining-industrial heritage of the Zaruma-Portovelo, ecuador, in the context of a geopark project. International Journal of Energy Production and Management, 5(1): 4859. https://doi.org/10.2495/EQ-V5-N1-48-59

[30] Su, X., Li, X., Kang, Y. (2019). A bibliometric analysis of research on intangible cultural heritage using CiteSpace. Sage Open, 9(2): 2158244019840119. https://doi.org/10.1177/2158244019840119

[31] Megerle, H.E. (2020). Geoheritage and geotourism in regions with extinct volcanism in Germany; Case Study Southwest Germany with UNESCO Global Geopark Swabian Alb. Geosciences, 10(11): 445. https://doi.org/10.3390/geosciences10110445

[32] Granados, P.C.G. (2011). Patrimonio geológico, una nueva veta para geoturismo. Revista Habitus. Semilleros de Investigación, https://doi.org/10.19053/22158391.1780

[33] Van Eck, N.J., Waltman, L. (2010). Software survey: VOSviewer, a computer program for bibliometric mapping. Scientometrics, 84(2): 523-538. https://doi.org/10.1007/s11192-009-0146-3

[34] Montalván-Burbano, N., Pérez-Valls, M., Plaza-Úbeda, J. (2020). Analysis of scientific production on organizational innovation. Cogent Business \& Management, 7(1): https://doi.org/10.1080/23311975.2020.1745043

[35] Zupic, I., Cater, T. (2015). Bibliometric methods in management and organization. Organizational Research Methods, $18(3)$ : https://doi.org/10.1177/1094428114562629

[36] Duque-Acevedo, M., Belmonte-Urena, L.J., CortésGarcía, F.J., Camacho-Ferre, F. (2020). Agricultural waste: Review of the evolution, approaches and perspectives on alternative uses. Global Ecology and Conservation, 22: e00902. https://doi.org/10.1016/j.gecco.2020.e00902

[37] Martínez-López, F.J., Merigó, J.M., Gázquez-Abad, J.C., Ruiz-Real, J.L. (2020). Industrial marketing management: Bibliometric overview since its foundation. Industrial Marketing Management, 84: 19-38. https://doi.org/10.1016/j.indmarman.2019.07.014

[38] Zhang, H., Liu, X., Yi, J., Yang, X., Wu, T., He, Y., Tian, P. (2020). Bibliometric analysis of research on soil water from 1934 to 2019. Water, 12(6): 1631. https://doi.org/10.3390/w12061631

[39] Ghose, A.K. (1990). Minerals, materials and developing countries - a forward look. in Minerals, Materials and Industry, Edinburgh: Edinburgh, 249-255.

[40] Bhattacharya, J. (2000). Sustainable development of natural resources: implications for mining of minerals. Mineral Resources Engineering, 9(4): 451-464. https://doi.org/10.1016/S0950-6098(00)00033-0

[41] Scoble, M., Daneshmend, L.K. (1998). Mine of the year 2020: Technology and human resources. CIM bulletin, 91(1023): 51-60.

[42] Wu, Q., Dong, D., Shi, Z., Wu, X., Sun, W., Ye, G., Liu, J. (2000). Optimum combination of water drainage, water supply and eco-environment protection in coalaccumulated basin of North China. Science in China Series D: Earth Sciences, 43(2): 122-131. https://doi.org/10.1007/BF02878141

[43] Streets, D.G., Tsai, N.Y., Akimoto, H., Oka, K. (2000). Sulfur dioxide emissions in Asia in the period 1985-1997. Atmospheric Environment, 34(26): 4413-4424. https://doi.org/10.1016/S1352-2310(00)00187-4

[44] Cragg, A.W. (1998). Sustainable development and mining: Opportunity or threat to the industry? CIM bulletin, 45-50.

[45] Cooney, J.P. (2000). People, participation and 
partnership. CIM Bulletin, 93(1037): 46-48.

[46] Rocha, J., Bristow, J. (1997). Mine downscaling and closure: an integral part of sustainable development. Minerals and Energy, 12(4): 15-20. https://doi.org/10.1080/14041049709409110

[47] Crowson, P. (1998). Mining and sustainable development: measurement and indicators. Minerals and Energy, 13(1): 27-33. https://doi.org/10.1080/14041049809409122

[48] Macklin, M.G., Brewer, P.A., Hudson-Edwards, K.A., Bird, G., Coulthard, T.J., Dennis, I.A., Turner, J.N. (2006). A geomorphological approach to the management of rivers contaminated by metal mining. Geomorphology, $\quad$ 79(3-4): 423-447. https://doi.org/10.1016/j.geomorph.2006.06.024.

[49] Custodio, E. (2002). Aquifer overexploitation: what does it mean? Hydrogeology Journal, 10(2): 254-277. https://doi.org/10.1007/s10040-002-0188-6

[50] Guo, H., Wang, Y. (2004). Hydrogeochemical processes in shallow quaternary aquifers from the northern part of the Datong Basin, China. Applied Geochemistry, 19(1): 19-27. https://doi.org/10.1016/S0883-2927(03)00128-8

[51] Sun, G., McNulty, S.G., Moore Myers, J.A., Cohen, E.C. (2008). Impacts of multiple stresses on water demand and supply across the Southeastern United States 1. JAWRA Journal of the American Water Resources Association, 44(6): 1441-1457. https://doi.org/10.1111/j.1752-1688.2008.00250.x

[52] Si, H., Bi, H., Li, X., Yang, C. (2010). Environmental evaluation for sustainable development of coal mining in Qijiang, Western China. International Journal of Coal Geology, $\quad 81(3)$ : https://doi.org/10.1016/j.coal.2009.11.004

[53] Wellmer, F.W., Becker-Platen, J. (2002). Sustainable development and the exploitation of mineral and energy resources: A review. International Journal of Earth Sciences, 91(5): 723-745. https://doi.org/10.1007/s00531-002-0267-x

[54] Mudd, G.M. (2007). An analysis of historic production trends in Australian base metal mining. Ore Geology Reviews, 32(1-2): 227-261. https://doi.org/10.1016/j.oregeorev.2006.05.005

[55] Teng, Y., Ni, S., Wang, J., Zuo, R., Yang, J. (2010). A geochemical survey of trace elements in agricultural and non-agricultural topsoil in Dexing area, China. Journal of Geochemical Exploration, 104(3): 118-127. https://doi.org/10.1016/j.gexplo.2010.01.006

[56] Mudd, G.M., Jowitt, S.M., Werner, T.T. (2017). The world's lead-zinc mineral resources: scarcity, data, issues and opportunities. Ore Geology Reviews, 80: 1160-1190. https://doi.org/10.1016/j.oregeorev.2016.08.010

[57] Morel, J.L., Chenu, C., Lorenz, K. (2015). Ecosystem services provided by soils of urban, industrial, traffic, mining, and military areas (SUITMAs). Journal of Soils and Sediments, 15(8): 1659-1666 https://doi.org/10.1007/s11368-014-0926-0

[58] Demirel, N., Emil, M.K., Duzgun, H.S. (2011). Surface coal mine area monitoring using multi-temporal highresolution satellite imagery. International Journal of Coal Geology, $86(1)$ :

3-11. https://doi.org/10.1016/j.coal.2010.11.010

[59] Gordon, J.E., Barron, H.F., Hansom, J.D., Thomas, M.F. (2012). Engaging with geodiversity - why it matters. Proceedings of the Geologists' Association, 123(1): 1-6. https://doi.org/10.1016/j.pgeola.2011.08.002

[60] Fassoulas, C., Mouriki, D., Dimitriou-Nikolakis, P., Iliopoulos, G. (2012). Quantitative assessment of geotopes as an effective tool for geoheritage management. Geoheritage, 4(3): 177-193. https://doi.org/10.1007/s12371-011-0046-9

[61] Khalil, A., Hanich, L., Bannari, A., Zouhri, L., Pourret, O., Hakkou, R. (2013). Assessment of soil contamination around an abandoned mine in a semi-arid environment using geochemistry and geostatistics: Pre-work of geochemical process modeling with numerical models. Journal of Geochemical Exploration, 125: 117-129. https://doi.org/10.1016/j.gexplo.2012.11.018

[62] Esmaeili, A., Moore, F., Keshavarzi, B., Jaafarzadeh, N., Kermani, M. (2014). A geochemical survey of heavy metals in agricultural and background soils of the Isfahan industrial zone, Iran. Catena, 121: 88-98. https://doi.org/10.1016/j.catena.2014.05.003

[63] Wang, X., Ding, W., Nan, Z., Liao, Q., Wu, W. (2013). Fraction of $\mathrm{Cd}$ in oasis soil and its bioavailability to commonly grown crops in Northwest China. Environmental Earth Sciences, 70(1): 471-479. https://doi.org/10.1007/s12665-013-2374-3

[64] Sawut, R., Tiyip, T., Abliz, A., Kasim, N., Nurmemet, I., Sawut, M., Ablimit, A. (2017). Using regression model to identify and evaluate heavy metal pollution sources in an open pit coal mine area, Eastern Junggar, China. Environmental Earth Sciences, 76(24): 1-13. https://doi.org/10.1007/s12665-017-7035-5

[65] Abbaslou, H., Bakhtiari, S., Hashemi, S.S. (2018). Rehabilitation of iron ore mine soil contaminated with heavy metals using rosemary phytoremediation-assisted mycorrhizal arbuscular fungi bioaugmentation and fibrous clay mineral immobilization. Iranian Journal of Science and Technology, Transactions A: Science, 42(2): 431-441. https://doi.org/10.1007/s40995-018-0543-7

[66] Wei, Z., Peng, L., Zhang, D.S., Yang, Z. (2018). A novel clean mining technology involving the underground disposal of waste rock in coal mines. Archives of Mining Sciences, 63. https://doi.org/10.24425/118887

[67] Goncharenko, L., Ryzhakova, A., Sedova, N., Efimov, I., Akulinin, F. (2019). Mining of mineral deposits. Developments in Heat Transfer, 13(4): 63-71. https://doi.org/10.33271/mining13.04.063

[68] Phillip, S., Andrew, S., Robert, S., Etienne, V.W. (2019). Towards sustainable mixed reality simulation for the mining industry. Min. Technol. Trans. Inst. Min. Metall, 128 :

246-254 https://doi.org/10.1080/25726668.2019.1645519

[69] Hose, T.A. (2012). 3G's for modern geotourism. Geoheritage, 4(1-2): 7-24 https://doi.org/10.1007/s12371-011-0052-y

[70] Bridge, G., McManus, P. (2000). Sticks and stones: environmental narratives and discursive regulation in the forestry and mining sectors. Antipode, 32(1): 10-47. https://doi.org/10.1111/1467-8330.00118

[71] Joyce, S., Thomson, I. (2000). Earning a social licence to operate: Social acceptability and resource development in Latin America. CIM Bulletin, 93(1037): 49-53.

[72] Glaister, B.J., Mudd, G.M. (2010). The environmental costs of platinum-PGM mining and sustainability: Is the glass half-full or half-empty? Minerals Engineering, 23(5):

https://doi.org/10.1016/j.mineng.2009.12.007 
[73] Zouros, N., Mc Keever, P. (2004). The European geoparks network. Episodes, 27(3): 165-171.

[74] Hirsch, J.E. (2005). An index to quantify an individual's scientific research output. Proceedings of the National Academy of Sciences, 102(46): 16569-16572. https://doi.org/10.1073/pnas.0507655102.

[75] Herrera-Franco, G., Montalván-Burbano, N., CarriónMero, P., Apolo-Masache, B., Jaya-Montalvo, M. (2020). Research trends in geotourism: A bibliometric analysis using the scopus database. Geosciences, 10(10): 379. https://doi.org/10.3390/geosciences10100379

[76] Hallinger, P., Kovačević, J. (2019). A bibliometric review of research on educational administration: Science mapping the literature, 1960 to 2018. Review of Educational Research, 89(3): 335-369. https://doi.org/10.3102/0034654319830380

[77] Van Eck, N.J., Waltman, L. (2014). Visualizing bibliometric networks. In Measuring Scholarly Impact, 285-320.

[78] Husain, V. (2005). Obstacles in the sustainable development of artisanal and small-scale mines in Pakistan and remedial measures. Geological Society, London, Special Publications, 250(1): 135-140. https://doi.org/10.1144/GSL.SP.2005.250.01.13

[79] Kwong, Y.J. (2003). Comprehensive environmental ore deposit models as an aid for sustainable development. Exploration and Mining Geology, 12(1-4): 31-36. https://doi.org/10.2113/0120031

[80] Shekhar, S., Kumar, P., Chauhan, G., Thakkar, M.G. (2019). Conservation and sustainable development of geoheritage, geopark, and geotourism: A case study of Cenozoic successions of Western Kutch, India. Geoheritage, 11(4): 1475-1488. https://doi.org/10.1007/s12371-019-00362-5

[81] Garcia-Ayllon, S. (2018). The Integrated Territorial Investment (ITI) of the Mar Menor as a model for the future in the comprehensive management of enclosed coastal seas. Ocean \& Coastal Management, 166: 82-97. https://doi.org/10.1016/j.ocecoaman.2018.05.004

[82] Vallega, A. (2007). The role of culture in island sustainable development. Ocean \& Coastal Management, 50(5-6): 279-300. https://doi.org/10.1016/j.ocecoaman.2007.02.003

[83] Zou, H. (2019). Study on soil ecological environment restoration strategy of abandoned mining area. Arabian Journal of Geosciences, 12(23): 1-7.

[84] Kuleta, M. (2018). Geodiversity research methods in geotourism. Geosciences, 8(6): 197. https://doi.org/10.3390/geosciences8060197

[85] Özşahin, E. (2017). Geodiversity assessment in the Ganos (Isıklar) Mount (NW Turkey). Environmental Earth Sciences, 76(7): 271. https://doi.org/10.1007/s12665-017-6591-z

[86] Xiao, W., Mills, J., Guidi, G., Rodríguez-Gonzálvez, P., Barsanti, S.G., González-Aguilera, D. (2018). Geoinformatics for the conservation and promotion of cultural heritage in support of the UN Sustainable Development Goals. ISPRS Journal of Photogrammetry and Remote Sensing, 142: 389-406. https://doi.org/10.1016/j.isprsjprs.2018.01.001

[87] Beraaouz, M., Macadam, J., Bouchaou, L., Ikenne, M., Ernst, R., Tagma, T., Masrour, M. (2019). An inventory of geoheritage sites in the Draa Valley (Morocco): a contribution to promotion of geotourism and sustainable development. Geoheritage, 11(2): 241-255. https://doi.org/10.1007/s12371-017-0256-x.

[88] Turner, S. (2006). Promoting UNESCO Global Geoparks for sustainable development in the Australian-Pacific region. Alcheringa: An Australasian Journal of Palaeontology, $30(\mathrm{~S} 1)$ : $351-365$. https://doi.org/10.1080/03115510609506872

[89] Dong, D., Chen, M.L. (2015). Publication trends and cocitation mapping of translation studies between 2000 and 2015. Scientometrics, 105(2): 1111-1128. https://doi.org/10.1007/s11192-015-1769-1 